(C)2019, Elsevier. This manuscript version is made available under the CC-BY-NC-ND 4.0 license http://creativecommons.org/licenses/by-nc-nd/4.0/

\title{
PARTICIPATIVE CO-CREATION OF ARCHAEOLOGICAL HERITAGE: case insights on creative tourism in Alentejo, Portugal
}

\author{
David Ross ${ }^{1} \&$ Gunjan Saxena ${ }^{2}$ \\ ${ }^{1}$ University of Exeter - Business School \\ ${ }^{2}$ University of Hull - Business School
}

\begin{abstract}
This paper focuses on the creative ingenuity of tourism providers in storying and providing varied readings of archaeological sites that have been physically lost. In conceptualising providers' efforts in mobilising (in)tangible aspects of archaeological heritage to accord them an inimitable identity and visible presence, we draw upon research on creativity and creative tourism. Our findings reveal how innovative meaning-making opportunities transform archaeological heritage into a valuable creative tourism resource that can be used to enhance the market appeal of local products and resources through theming and creative storytelling. Overall, this study contributes to nascent work on participative co-creation of archaeological heritage that can serve as an effective means of creating meaningful interpretive experiences at cultural tourism destinations.
\end{abstract}

Keywords: cultural heritage; creative tourism; heritage interpretation; co-creation; archaeological tourism; destroyed heritage

\section{INTRODUCTION}

While there are many channels to communicate the past and engage with archaeological knowledge, standard approaches to managing archaeological heritage as a cultural tourism resource still centre mostly on the provision of an experiential engagement with the material remains of the past (McManamon, 1993; Ramsey \& Everitt, 2008; Willems \& Dunning, 2015). Such significance ascribed to the material dimension of heritage implies that dynamic processes that encapsulate the intangible are ill accounted for and inadequately supported in cases in which physical fabric is lost.

In general, preventive archaeology projects aimed at identifying, recording, evaluating and managing historical sites for posterity focus on monumentality and aesthetic value at the expense of other aspects (Demoule, 2012). For instance, the construction of dams often leads to the submergence of archaeological remains. Although developers undertake measures to preserve knowledge about the region's past, conventional approaches to developing 
archaeological tourism do not capture fully the complexity required to maintain effective engagement with the local heritage in the post-dam scenario when physical remains are unavailable (Adams, 2007; WCD, 2000). Similarly, an archaeological site that has been excavated acquires new meanings in the process of losing its tangible heritage. Indeed, authors underscore how intangible elements of archaeological heritage (e.g. scientific knowledge, local memory and values associated to the historical remains and emotions they evoke in individuals) keep it alive in collective memory (Carboni \& de Luca, 2016; Ross, Saxena, Correia, \& Deutz, 2017). This paper extends these theoretical debates by demonstrating a complex and contradictory series of processes underpinning creative enterprise of providers in the selling of (im)material resources and spaces and making them desirable for tourists.

Our aim is to examine the tourism potential of (in)tangible archaeological heritage and the role of providers in creating memorable experiences from it. This work demonstrates how the creative ingenuity of tourism providers not only offers a framework for the symbolic construction of the past, but also enhances what Crang and Tolia-Kelly (2010) call "the affective energy and emotive force of heritage" (p. 2316). Thus, while like Crang and ToliaKelly we are interested in the (in)tangibility of heritage sites, our concern is more with classifying and cataloguing processes that underlie the (re)making of physically inaccessible archaeological heritage, encapsulating fluid and dynamic facets of a region's histories and interpretations. Overall, our work has a two-fold focus: i) to what extent can archaeological heritage that has been destroyed or relocated serve as a potential cultural and creative tourism resource? and ii) what role does the mosaic of traditions, creative interpretations and experiences embodied by tourism providers play in conceptualising their role in commodifying archaeological heritage? In doing so, we respond to authors' calls for "putting the soul into archaeology" (van der Linde, van den Dries, \& Wait, 2018, p. 181) by taking a creative, interpretive approach that engages with multiple notions of what constitutes heritage to inspire and relate with a wider range of audiences. The emphasis is on both emotive narratives and scientific interpretations that provide more interactive or adaptive experiences to visitors (Roussou, Ripanti, \& Servi, 2017; van der Linde \& van der Dries, 2015).

In the next section, following a review of research on providers' creative interpretations linked to conservation approaches of cultural heritage, we present our conceptual framework underlining how participative co-creation of archaeological heritage embodies varied activities that may be perceived as diverging from routine ways of thinking, but that allow both tourists and providers an outlet for realising their creative potential and engaging with notions of the past. The paper then illustrates how the memory of archaeological monuments is used as a 
tourism resource in Alentejo (Portugal) and elaborates upon the constructivist research design we followed. Our findings illustrate how, even in cases of total physical absence, archaeological sites remain entangled with the lives of both locals and tourists, instilling feelings of an intricate connection and accountability. Indeed, as Shurmer-Smith and Hannam (1994) underscore, heritage conservation is not simply about conserving the traces of the past, but also about actively (re)creating and sustaining the reality of the world that has been destroyed to minimise its disappearance symbolically. The paper concludes with an emphasis on the need to infuse archaeological discourse with providers' creative (re)presentations that can inform the design and development of evocative experiences at heritage-rich destinations.

\section{LITERATURE REVIEW}

The use of archaeological heritage as tourism resource entails its conversion into a modern commodity through a process of careful selection and elimination to direct the tourist's gaze towards particular facets (Hubbard \& Lilley, 2000). However, the process of promotion and marketing of heritage sites and securing a new economic role for them is often conceived from the perspective of consumption rather than production (Waitt \& McGuirk, 1997). Thus, providers' tactics in developing creative tourism and re-imagining the role of resources, either tangible or unavailable/non-viable, at sites that appear to have less to offer are often overlooked. Therefore, in our conceptual frame, we emphasise integrating the field of archaeological tourism with research on creativity to theorise the role of tourism providers in formulating innovative approaches to interpret and manage physically inaccessible archaeological heritage as they infuse localities with a unique sense of place.

\subsection{Providers' creative interpretations of heritage}

Creativity is defined as an interplay between an ability and processes by which an individual or group produces an outcome or product that represents an attempt "to propel a field from wherever it is ... to wherever the creator believes it should go" (Sternberg, Kaufman, \& Pretz, 2002, p. 10). The physical loss of historic remains provides a suitable opportunity to (re)state creatively a place's identity based upon the subjective readings of the erased site by underscoring particular memories and values and expunging others that are considered less desirable (Fibiger, 2015; Holtorf, 2015). De Cesari (2010) illustrates how a cultural event like the Palestinian Biennale embodies creative aspirations of local nongovernmental and semigovernmental groups in Palestine engaged in (re)interpreting the vernacular heritage of historic homes and urban neighbourhoods. Also, it provides a space for transforming “. . . the West 
Bank into a centre of cosmopolitan cultural production - a node in a network crisscrossing the globe rather than the prison like enclave of Palestinians' daily experience" (p. 628). Indeed, providers' creativity transcends the act of mere preservation of the heritage, becoming a means of engendering new socialities and diverse meanings/subjectivities attached to historic places and objects (De Cesari, 2010; Simpson, 2018). Building on these ideas, DeSilvey (2017) examines threatened heritage sites and argues that the physical decay of historical monuments presents an opportunity to rethink and experiment novel conservation approaches that are emblematic of local sensibilities and invest in their sensitive transformation and reinvention. These views frame heritage as a renewable resource, continuously undergoing transformation and recreated by persistent human intervention (Holtorf, 2008).

Despite these positions on providers' creative potential in the (re)interpretation of heritage, approaching erased archaeological heritage from a tourism perspective is challenging because initiatives focusing on them have been scarce and lack a discrete template embodying mitigatory practices and policies (Huvila, 2017). Furthermore, tourism uses of heritage are still focused commonly on visitors' passive consumption of deterministic and definitive narratives of the past (Jorgensen, Dobson, \& Heatherington, 2017). Certainly, in developer-funded archaeological tourism initiatives, apart from museums and exhibits, little use is made of discursive accounts reflecting varied layers of a site's socio-cultural aspects (Goudswaard, Bos, van Roode, \& Pape, 2012). Nevertheless, studies are beginning to consider that heritage can be reframed via discourse and conscious (re)creation of meanings that best reflect its essence in the contemporary context (Jorgensen et al., 2017; Smith, 2006; Wu \& Hou, 2015). Goudswaard et al. (2012, p. 102) introduce the term "reverse archaeology" and suggest that archaeological knowledge produced in developer-funded archaeology contexts can add place-inspired character to enhance the spatial quality of the proposed development as well as the site's touristic appeal. Warnaby, Medway, and Bennison (2010) present a convincing case in favour of marketing of places with diminished materiality such as the Hadrian Wall, which owes its fuzziness to a lack of fixed borders, with tourism serving as a means of "tangibilising the intangible" (Warnaby et al., 2010, p. 1369).

Also relevant is the concept of "attraction residuality", that is, "the perpetuation of an attraction in the aftermath of its physical loss" (Weaver \& Lawton, 2007, p. 110), which enables preserving the memory of destroyed historical sites via reconstruction, memorialisation or redefinition. Reconstruction of a lost attraction can take place either in-situ or ex-situ, as in the cases of the Lascaux and Altamira grottos that have been replicated due to the deterioration of the original cave paintings (Parga \& González, 2019). Virtual reconstruction of destroyed sites 
using digital technologies also allow users to experience a sense of place (Ellenberger, 2017). Memorialisation can happen through mechanical reproduction such as souvenirs or through social simulation, including events celebrating the memory of the lost attraction (Kersel \& Luke, 2004). Finally, redefinition concerns reinventing the lost attraction in new moulds and implies accepting its loss through the re-creation of meaning and memory.

Approaches to retain lost heritage such as digital reconstruction or organising annual festivities are mostly beyond the reach of small and micro-cultural tourism providers. Nevertheless, these actors play a key role in sustaining subtle and nuanced conceptualisations of a site's past and countering the prevailing, even hegemonic, perspectives. Thus, this study aims to fill a key gap by proposing a framework of participative co-creation of archaeological heritage that acknowledges the role of providers' constructivist heritage interpretation strategies in materialising the potential of archaeological heritage as both a constituent factor of place identity and a source of inspiration for their entrepreneurial activities. Our study is significant because providers' role in creative interpretation of archaeological sites remains underresearched.

\subsection{Participative co-creation of archaeological heritage for tourism}

We consider the participative co-creation of archaeological heritage for tourism purposes a composite of activities that allow tourists and providers a greater role in crafting experiences that offer an outlet for their creativity as a means of making sense of historical sites and the past. At its heart is the role of memories, stories and actors' creative aptitude that anchor archaeological sites to the present and transform them into resources for cultural and creative tourism. Conventional approaches to managing archaeological tourism tend to emphasise more on safeguarding heritage in a top-down manner that reinforces specific meanings and values at the expense of others. In contrast, we engage with the (in)tangible to account for historic remains as well as individuals' experiences, thoughts, feelings and attitudes in shaping experiences and sensibilities towards archaeological heritage. 
Our contention is that the participative co-creation of archaeological heritage is a potent tool to facilitate an emotional connection not only with its (in)tangible aspects, but also serves as means of reimagining their relevance in contemporary cultural and creative tourism initiatives. Indeed, this experience-centred approach is well-suited to leverage creatively the interpretive skills of providers in their role of facilitators for the tourist's sense-making experience (see Fig. 1).

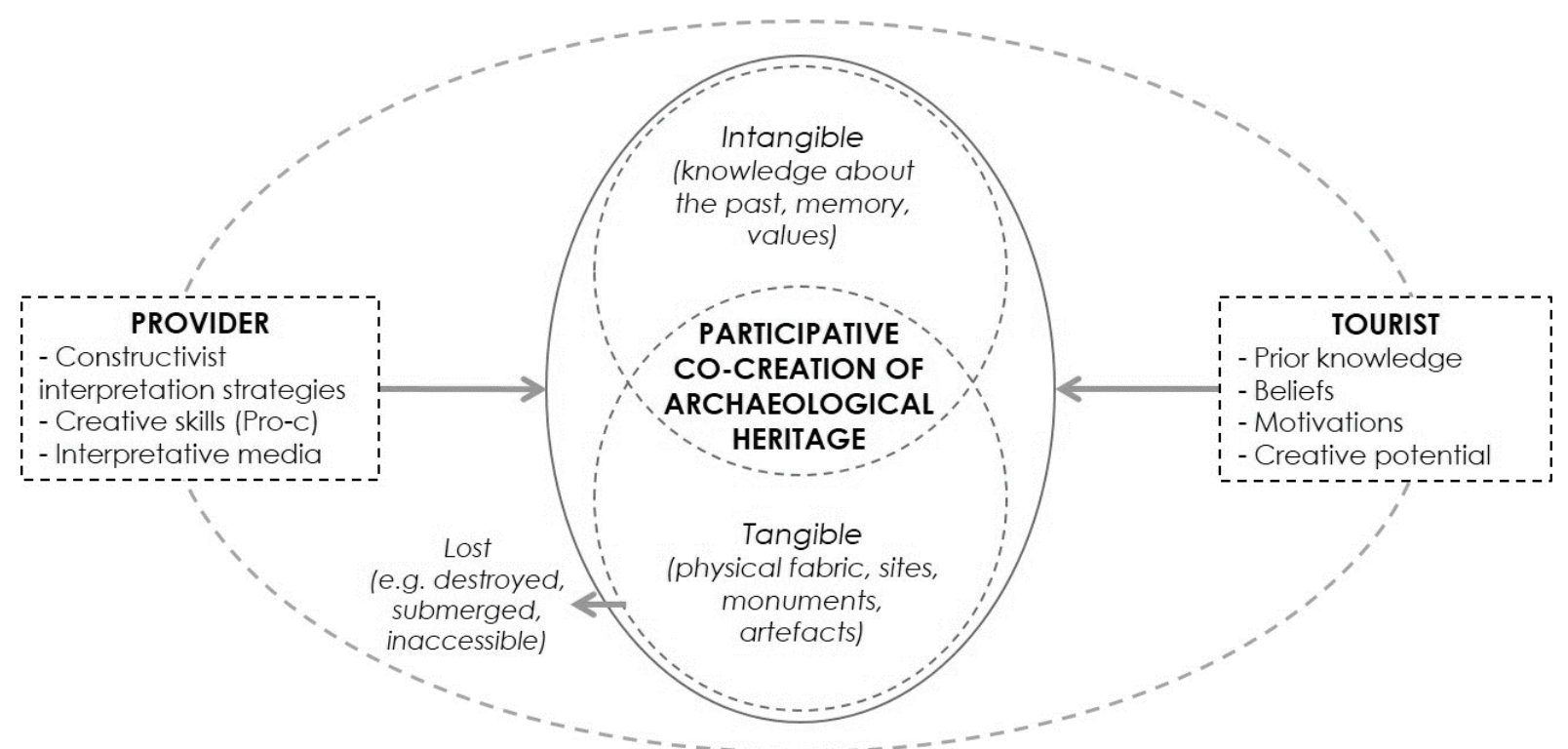

Figure 1. A framework of Participative Co-creation of Archaeological Heritage. Source: authors.

Following Amabile (1983), our concern is with the social psychology of creativity. Thus, providers' creativity is best conceptualised not as a sum of customary personality traits, but as behaviour emanating from “. . . particular constellations of personal characteristics, cognitive abilities, and social environments" (p. 358). Moreover, when examining the creative processes underlying the use of archaeological heritage as a tourism resource, a relevant approach is the investment theory of creativity, in which the emphasis is on the effort creative people employ in identifying a little known idea and work on it to improve its value (Sternberg \& Lubart, 1991, 1996). Particularly, the investment theory of creativity assumes that ideas already exist, and what is required is the creative individuals' ability to identify and materialise their potential (Sternberg, 2012).

Furthermore, while creativity as a concept is difficult to attribute to one particular factor, it can be mapped on a continuum ranging from the lower levels of everyday creativity to historically significant advances in the arts and science (Fig. 2). It can be characterised into Little and Big creativity whereby "Little-c" refers to creativity applied in everyday chores (such 
as playing music) and "Big-c" to breakthrough ideas that significantly change the way a field is perceived (Gardner, 1993; Richards, 2010). Kaufman and Beghetto (2009) suggest two additional levels of creative ability. Accordingly, "mini-c" creativity is applied during learning, allowing to distinguish the creative process of an initial learner from an advanced learner applying little-c creativity (Beghetto \& Kaufman, 2007). "Pro-c" sits between Little and Big creativity and describes those who have developed professional expertise in a field without producing an effective change (Lin \& Baum, 2016).

\begin{tabular}{|c|c|c|c|}
\hline Mini-c & Little-c & Pro-c & Big-C \\
\hline $\begin{array}{c}\text { Creative } \\
\text { interpretation } \\
\text { associated with } \\
\text { the intrapersonal } \\
\text { process of } \\
\text { learning }\end{array}$ & $\begin{array}{l}\text { Everyday } \\
\text { creativity applied } \\
\text { in daily problem- } \\
\text { solving or hobbies }\end{array}$ & $\begin{array}{c}\text { Creative } \\
\text { contributions that } \\
\text { do not effectively } \\
\text { or significantly } \\
\text { change the } \\
\text { domain }\end{array}$ & $\begin{array}{c}\text { Creative } \\
\text { breakthroughs } \\
\text { that have } \\
\text { changed the } \\
\text { course of the } \\
\text { domain }\end{array}$ \\
\hline
\end{tabular}

Figure 2. Four levels of creativity. Source: adapted from Kaufman and Beghetto, 2009.

Furthermore, co-creation occurs when both tourism providers and tourists come together to create and perform the creative tourism experience (Binkhorst \& Den Dekker, 2009; Campos, Mendes, Valle, \& Scott, 2015). This means that the creative tourism experience focuses not only on external elements (e.g. heritage site), but on providers' creative capacity and tourists' personal tastes and preferences in defining the value they derive from it (Richards \& Wilson, 2006). In fact, actors' imaginative and participative co-creation is shaped by their prior experiences, embodied memories and media representations, including expert and lay narratives and prescribed emotions associated with sites, objects, and practices inherent therein, and underpins the situational affective context of heritage (Rana, Willemsen, \& Dibbits, 2017).

Following this line of thinking, creative tourism providers use heritage to offer an experience that tourists co-create according to their own interests, knowledge and expectations (Prebensen, Vitters $\varnothing$, \& Dahl, 2013; Vargo \& Lusch, 2004). An explicit form of co-creation in heritage tourism is through heritage interpretation, which is broadly perceived between positivist and constructivist approaches. Positivist interpretation offers visitors a narrative focused on factual information and experts' interpretations (Smith, 2006). This didactic approach values explanation of the historical site, viewing visitors as passive consumers of knowledge that they have little means of changing (Youngentob \& Hostetler, 2003). 
Constructivist interpretation is rooted in the assumption that the past is individually and socially constructed (Hein, 1998). As one of the reviewers highlighted, the meaning-making and experiences take place within socially constructed frames that confirm, negotiate or break away from established normative codes. Thus, visitors are encouraged to come up with their own interpretations of the heritage site based on their values and prior knowledge (Copeland, 2006). In other words, the core value proposition is the process of engaging with the past that offers individuals a chance to make sense of the historic site and situate it within their worldviews. This approach thus arguably shifts the attention away from an interaction with the actual physical fabric towards an immersive process of creative sense-making. We now present our case context of Alentejo in Portugal and then discuss our research design and analytical measures employed.

\section{STUDY METHODS}

\subsection{Archaeological Heritage in Alentejo}

Alentejo's tourism image is predicated on its countryside and rurality as well as cultural heritage and historic sites from megalithic, Roman and medieval ages. The construction of the Alqueva dam in 2002 created the largest artificial lake in Western Europe, representing a major turning point for local farming that was frequently affected by severe drought (Fig. 3). Given the region's archaeological richness, Alqueva dam construction plans included extensive preventive archaeology surveys that significantly augmented knowledge of Alentejo's past, despite the submersion of many sites (Silva, 2002). Some foremost monuments affected include Castle of Lousa (a listed Roman fortification submerged beneath the reservoir) and Xerez Cromlech (a prehistoric monument that was relocated to avoid submersion), as well as other smaller sites. The community of Luz village was also relocated, an event that attracted substantial media attention. 


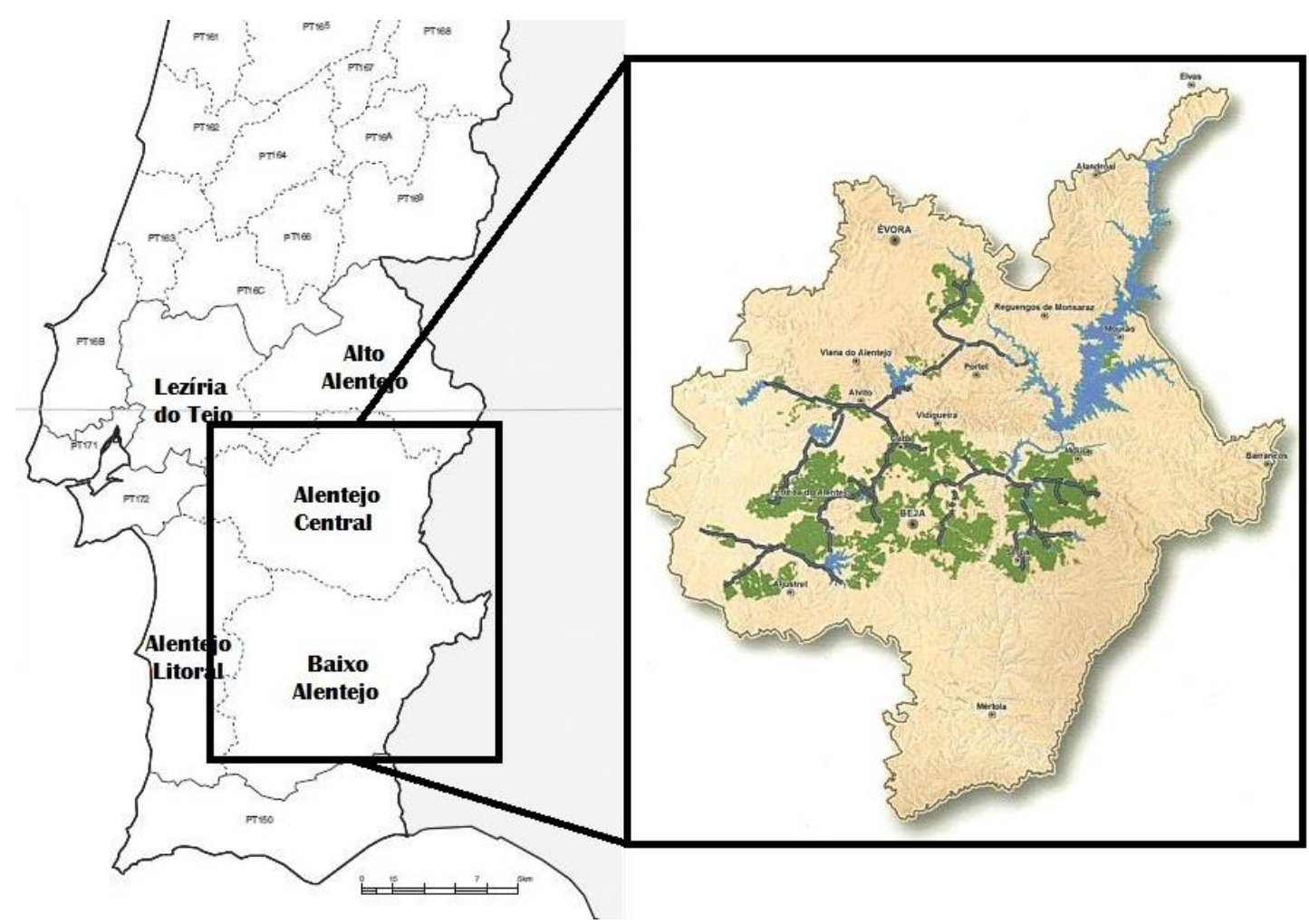

Figure 3. Map of Alentejo highlighting Alqueva dam primary and secondary reservoirs (blue) and irrigation system (green). Source: adapted from Eurostat, 2004; EDIA.

For the tourism sector, however, the dam did not produce significant impact (DiasSardinha \& Ross, 2015). Despite their tourism potential, the official strategic plan for the development of Alentejo's cultural tourism overlooks submerged archaeological monuments (Turismo do Alentejo, 2015). In fact, plans to build a regional archaeological museum in the early 2000s were thwarted due to limited funding. The Alentejo region is a representative example to study the tourism potential of archaeological heritage given that a) it is a cultural tourism destination with many archaeological sites; and b) the Alqueva dam construction has rendered a number of archaeological sites inaccessible to the public. Given this context, the paper explores providers' creative capacity, values and interpretation strategies in enlivening different storylines supporting the region's archaeological heritage.

\subsection{Research Approach}

This study is underpinned by a constructivist research paradigm. Cultural heritage is a social construct built upon the ideas, notions and perceptions inherently subjective to individual members of a cultural group (Cohen, 1988; Smith, 2006). Our constructivist approach enabled the research to accommodate the complexity of multiple perceptions of archaeological heritage and understand how actors engage with it to secure tourism development. 
Data were collected from three sources: 1) interviews with public, non-profit and private tourism providers of Alentejo; 2) observations conducted during field trips to Alentejo; and 3) promotional materials of cultural tourism companies and organisations of Alentejo. The diverse set of stakeholders allowed an examination of tourism uses of archaeological heritage from different angles, providing a richer picture of the Alentejo destination and its archaeological heritage (see Table 1). Participants were selected through purposeful sampling and included:

a) private tourism actors, mostly micro-businesses employing one to two people, that offer cultural tours to local archaeological sites in the region surrounding Alqueva lake;

b) public actors that use local archaeological heritage for tourism promotion and develop heritage awareness initiatives; and

c) non-governmental organisations that develop activities for heritage awareness and promotion in local communities.

\begin{tabular}{cl}
\hline \multicolumn{1}{c}{ Sector } & \multicolumn{1}{c}{ Position (business/organisation) } \\
\hline & Tour guide (sole proprietor business-part-time) \\
& Tour guide (family business_-part-time) \\
& Tour guide (freelance) (x2) \\
& Tour guide (freelance-part-time) \\
& Tour guide (sole proprietor business) (x2) \\
Private & Tour guide (two-person business partnership) \\
& Tour guide (two-person business partnership-part-time) \\
& Manager/owner (boat tour company) \\
& Tour guide (family business) (x2) \\
\hline & Council archaeologist (city council) (x2) \\
& General secretary (regional tourism promotion agency) \\
& Director of Heritage Department (Alqueva dam developers) \\
& Executive manager (local museum) \\
& Director (regional museum) \\
& Town mayor (city council) \\
& Archaeologist (regional culture heritage agency) \\
\hline \multirow{5}{*}{ Public } & General secretary (regional business association) \\
& Manager (regional development association) \\
& General secretary (regional development association) \\
& General secretary (cultural heritage foundation) \\
& Manager (tourism business network)
\end{tabular}

Table 1. Profile of Participants

In all, 39 public actors, non-governmental organisations and cultural tourism businesses were identified, all of which were contacted by email first and then by telephone. 
Eight actors did not respond, whereas six others declined or were unavailable to participate within the time frame. In the end, 25 participants were interviewed between July and November 2016.

\subsection{Interview guide and procedure}

Interviews were semi-structured and comprised of open-ended questions and show cards while simultaneously allowing the flexibility for interviewees to discuss other topics they might consider relevant (Bryman, 2012; Flick, 2014). Open-ended questions were adapted loosely from the audit tool developed by McKercher and Ho (2006) to assess the potential of heritage assets in delivering memorable tourism experiences according to four dimensions-cultural, physical, product and experiential values. Although the tool was developed originally to assess mainly tangible heritage sites, we found it equally useful in documenting providers' perceptions of physically inaccessible archaeological heritage and their strategies in utilising it as a resource for the enhancement of their business. Examples of questions asked include: what is the cultural significance of the archaeological sites that have been physically destroyed? In what ways is the memory of these sites capable of providing participatory, engaging and/or entertaining experiences? How are they enlivened to make the past relevant and understandable in the context of rapidly changing socio-cultural settings?

Following these questions, five show cards with questions about co-creation of the archaeological tourism experience were shared with participants (Table 2), creating a direct channel between the participant and the literature (Lynn, 2004; Morgan, Elbe, \& Curiel, 2009). Each card contained two sentences representative of positivist and constructivist strategies of cultural heritage interpretation, and each was handed out one at a time. Participants were asked to reflect on their role in the co-creation of participatory experiences around archaeological heritage and to comment on their experience and views concerning the interpretation strategies around historic sites mentioned in literature.

\begin{tabular}{ccc}
\hline $\begin{array}{c}\text { Card } \\
\text { number }\end{array}$ & Positivist approach & Constructivist approach \\
\hline 1 & $\begin{array}{c}\text { The tourism provider should highlight } \\
\text { specific details and facts about the } \\
\text { archaeological site. }\end{array}$ & $\begin{array}{c}\text { The tourism provider should highlight the } \\
\text { wider historical context of the } \\
\text { archaeological site. }\end{array}$ \\
\hline 2 & $\begin{array}{c}\text { The tourism provider should convey } \\
\text { experts' interpretation of the } \\
\text { archaeological site. }\end{array}$ & $\begin{array}{c}\text { The tourism provider should promote the } \\
\text { tourists' contact with the archaeological } \\
\text { site and encourage their own interpretations. }\end{array}$ \\
\hline 3 & $\begin{array}{c}\text { The tourism provider should offer an } \\
\text { objective and universal portrait of the }\end{array}$ & $\begin{array}{c}\text { The tourism providers should adapt their } \\
\text { speech according to the tourist's prior }\end{array}$ \\
\hline
\end{tabular}




\begin{tabular}{ccc}
\hline archaeological site and the past. & $\begin{array}{c}\text { knowledge about the archaeological site } \\
\text { and the past. }\end{array}$ \\
\hline 4 & $\begin{array}{c}\text { The aim of archaeological tourism is to } \\
\text { instruct tourists about the history and } \\
\text { archaeological heritage of the region. }\end{array}$ & $\begin{array}{c}\text { The aim of archaeological tourism is to use } \\
\text { archaeological heritage to provoke creative } \\
\text { thinking and discussion about the past. }\end{array}$ \\
\hline 5 & $\begin{array}{c}\text { The tourist experience should be linear } \\
\text { and observe a set of predetermined } \\
\text { steps. }\end{array}$ & $\begin{array}{c}\text { The tourist's experience should allow and } \\
\text { encourage free exploration of the } \\
\text { archaeological site. }\end{array}$ \\
\hline
\end{tabular}

Table 2. Show cards.

The overall emphasis was on underscoring individual and collective ontological security and meaning-making providers derive from the region's heritage.

\subsection{Data analysis}

All interviews lasted nearly an hour on average and were tape-recorded. While the first author conducted all interviews due to the familiarity with the local language, data were analysed jointly by the research team employing a thematic analysis approach with the aid of Nvivo 11 . The thematic analysis of qualitative data consisted of indexing sections of each interview to a specific code (Gibbs, 2007). In practice, this was achieved through a process of critical analysis of the interview transcripts with the aim of identifying categories or themes in the data. In most cases, attention was directed towards the frequency of each idea mentioned by participants, given that "an emphasis on repetition is probably one of the most common criteria for establishing that a pattern within the data warrants being considered a theme" (Bryman, 2012, p. 580). Codes were then grouped into themes and sub-themes, finally forming a thematic tree of the data (Saldaña, 2013). In addition, we undertook an analysis of newspaper stories and tourist blogs relating to local archaeological heritage to further gain an understanding of its touristic potential and its influence on both providers' tactics and tourists' sensibilities.

Together, these helped shape the discussion on three key themes relating to how Alentejo's archaeological heritage is experienced and commodified: i) physical loss as an element of attractiveness; ii) themed activities; and iii) creative storytelling. Our analysis focused on the triangulation of interview data with field notes and an examination of local tourism promotional materials used by actors in all three sectors.

\section{DISCUSSION AND ANALYSIS}

This section discusses participants' roles and creative skills in enhancing the tourism potential of Alentejo's archaeological heritage as they calibrate their creative practices to infuse it with 
new meanings. The real value of participative co-creation of archaeological tourism lies in the successful (re)creation of meaningful experiences whereby interface with the heritage is optimised despite the physical loss. Thus, we focus on the role of providers' skills and the interconnected nature of their ties with the region's history, relics and the wider community in bringing alive the simultaneously real yet non-existent elements of Alentejo's archaeological heritage.

\subsection{Physical loss as an element of attractiveness}

Data collected in Alentejo suggest that while submerged heritage has lost its capacity to be physically experienced, the story of its destruction is serving as an "identity-building block" in its "heritagisation process" (Svensson, 2018, p. 269) as providers and visitors engage in the cocreation of its appeal and archaeological knowledge production. In Alentejo, this appeal of loss is evident in the case of the submerged Castle of Lousa and the Museum of Luz located nearby (see Fig. 4).
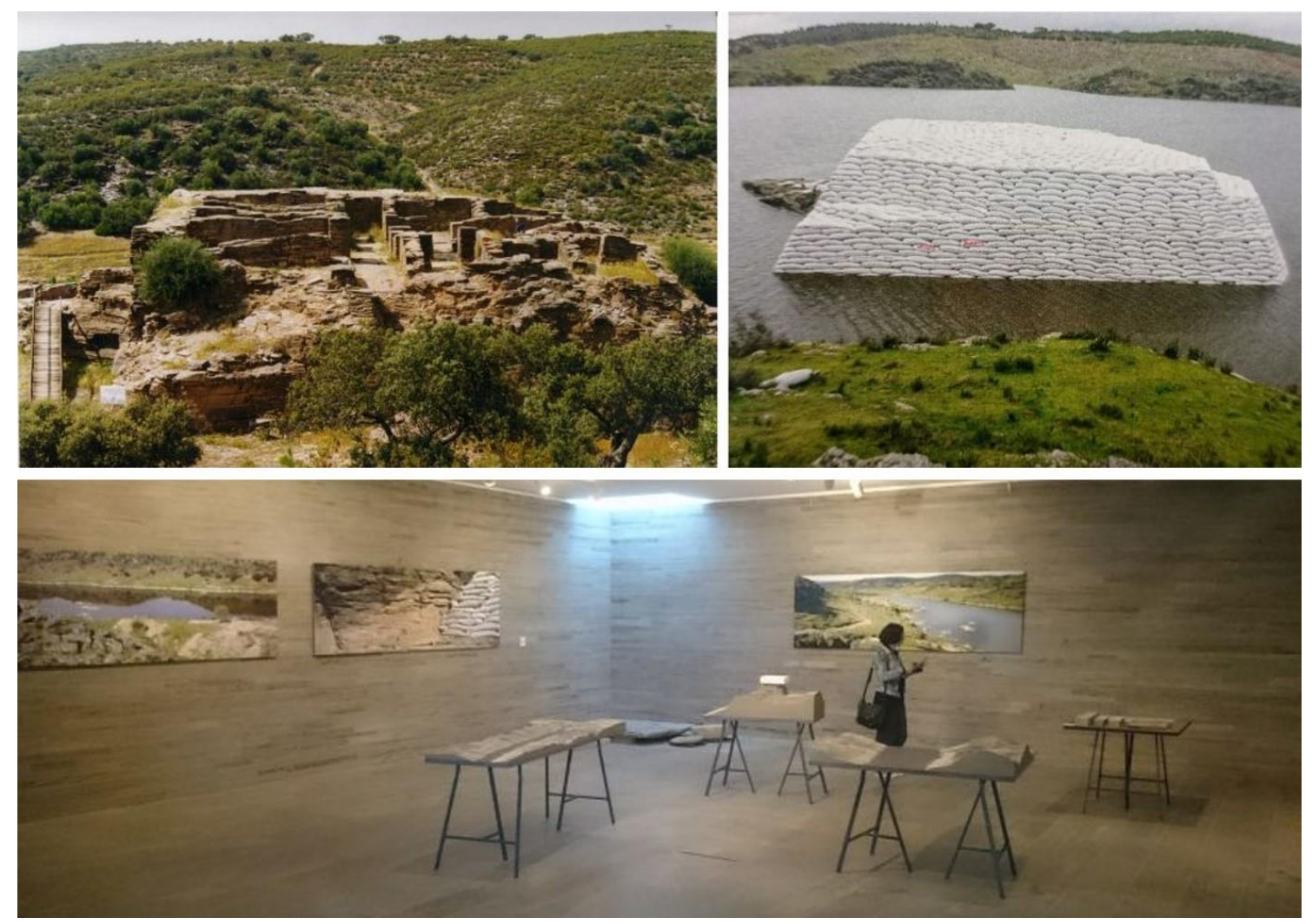

Figure 4. Castle of Lousa as it was before submersion (top left), under protective cover during rising water (top right), and memorialised in museum exhibition (bottom). Source: EDIA; authors.

At the time the fieldwork was conducted, the museum had a temporary exhibition about the Castle of Lousa that highlighted its submersion. Topographical models depicted the 
monument's original form before submersion, and pictures on the wall illustrated the protective cover of sandbags guarding the monument from floodwater erosion (see Fig. 4). Now, the museum focuses on offering an immersive experience to visitors accomplished via the visuals of the submerged castle and the creative narrative skills of tour guides who elaborate eloquently upon the process of moving through loss to resigned acceptance of how it once was-antes da barragem.

Gradually, with time, the emphasis of prevalent narratives has shifted more towards the flooding of Castle of Lousa and the fact that it is still intact and protected (although submerged) than the monument's actual history. The Alqueva dam developer explained how:

The Castle of Lousa has taken on a new life, as if 'renasceu' (reborn) in the wake of the Alqueva dam construction. Usually sites are destroyed but we sealed it in order to preserve it which has captured visitors' imagination and sparked renewed interest in an otherwise ignored monument (25 October 2016).

Indeed, the interview with the director of the Museum of Luz revealed how this theatrical depiction of the region's past is inducing what Boyd (2012) calls "cognitive ownership" (p. 176) whereby the link between people and place is cemented via mutually derived and mutable intellectual, conceptual and/or spiritual meanings. She explained how the monument was located previously on a private property with difficult access by road and had been mostly ignored. However, there was a rush among locals to see it one last time as news spread of its submersion and unusual method of preservation (encasing it within a sandbag sarcophagus), which has since resulted in its "reinvention", as a local archaeologist notes in his blog (Silva, 2015). For most providers, it is the physical destruction rather than the castle's appeal per se that continues to influence both their perception and efforts at co-creation of the region's heritage. This counters Weaver and Lawton's (2007) stipulation that attraction residuality is influenced by the appeal it has prior to destruction. The Castle of Lousa was not a widely known attraction, but its loss has made it a focal point in the interpretative processes contiguous to the region's archaeological tourism initiatives.

Another example is the Xerez Cromlech, a square-shaped prehistoric henge that was relocated to higher grounds to avoid it being submerged (Silva, 2004). Although it is still accessible, many participants argue that relocating the monument has affected both its historic and tourism value, reasoning that the monument's astronomical alignment has been irrevocably wiped out. This perceived loss of authenticity follows Timothy and Boyd (2003, p. 247) contention that “. . . moving buildings and other artefacts to non-original places diminishes their heritage value, for historical resources acquire a higher value for the public when developed in 
their original sites". Nevertheless, the Xerez Cromlech is still included in many tours, mainly because it was the only large monument to be relocated due to Alqueva dam.

I always speak about the Xerez Cromlech because it is one of the few examples that was relocated. It has since lost its value. However, I find it interesting to engage visitors in debates pertaining to move or not to move-similar to what you find in Shakespeare To be, or not to be ... (laughs) (tour guide, female, 15 June 2016).

In this case, the conceptual loss caused by the removal of a monument from its original site has added to Xerez Cromlech's appeal because tourism providers offer imaginative narratives replete with the monument's relocation instead of its inherent historical value. Thus, in both instances, the appeal of loss associated with the Castle of Lousa and Xerez Cromlech - whether physical or conceptual - is appropriated and contested by providers to cultivate visitors' affinity with the reworked aspects of the landscape.

Undeniably, the knowledge of destroyed archaeological sites complements existing products and resources, adding a "mystical" element to the overall tourism experience that the region has to offer:

A heritage hidden from sight creates a certain appeal . . . the Alqueva lake is not just a lake - it's a lake that holds secrets and stories around heritage that lies submerged ... you cannot see it on the surface, but can feel it with your mind's eye-we help deliver its mental picture and create a desire to make people want to visit it (Dark Sky Alqueva project manager, non-profit tourism network established in 2009).

This idea that "the lake is not just a lake", but an entity associated with a wealth of submerged heritage, holds immense marketing potential. Indeed, the boat-rental company in Alqueva reservoir offers a local guidebook and map that mention submerged archaeological heritage to pique visitors' intrigue. The guidebook signposts the lost space, indicating its inaccessibility via the informative text about various archaeological interventions that were carried out during the construction of the dam, while the navigation map points out and describes several submerged monuments. In addition to these materials, an on-board movie and guides on boat tours highlight submerged monuments. These cases emphasise how the memory of destroyed archaeological sites is used as a supporting feature that enhances a peak experience (e.g. the boat tour) and transfers to other local products or resources (e.g. retail, wildlife, lake) (Quan \& Wang, 2004).

The submerged monuments well illustrate how the intangible is "humanised" (AbuKhafajah \& Rababeh, 2012, p. 78) through people's imaginations, stories and traditions. From a planning and marketing perspective, a key advantage resulting from the lessened materiality is that archaeological heritage "can be more easily reimaged and redefined to create dramas of 
context" (Warnaby et al., 2010, p. 1378) that suit particular actors' agenda. Alentejo's tourism providers - private companies, non-profit making/governmental bodies and dam developersare all using the region's archaeological heritage to promote different storylines according to their schemas and individual skills.

\subsection{Themed activities}

Furthermore, inspired artistic activities (e.g. re-enactments and artworks) embody the transformative potential of creative and critical work undertaken in relationship to not only developing a reasoning around archaeological heritage, but also galvanising perception and provoking creative responses (Weaver \& Lawton, 2007). Themed activities situate the creative potential of both tourists and providers at the core of the entire enterprise of local archaeologyrelated tourism initiatives using archaeological heritage as means to mediate between people, data and the immateriality of the heritage in conceptualising Alentejo's past. A re-enactment that well illustrates the creative skills of tourism providers takes place during the annual Endovélico Festival.

The name 'Endovélico' refers to a pre-Roman deity once worshipped in the Iberian Peninsula. Archaeological research has ascertained that the largest known temple dedicated to the deity was located originally on a hill near the town of Alandroal, in Alentejo (Guerra, Schattner, Fabião, \& Almeida, 2003). In the present day, there are no visible ruins of the temple, yet the Endovélico Festival infuses this stark landscape with themed activities such as historical re-enactments of pagan worship, seminars and guided walking tours. The lack of the temple's material remains does not seem to affect the festival's popularity. In fact, one of the event's highlights is a procession to the top of the temple hill culminating with a re-enactment of the pagan worship of the Endovélico deity. Alandroal's council archaeologist explained:

An altar table is set up on the hill and re-enactors pray to the gods. The audience also participates in the service, they hold hands and embrace at the end. They form a large circle by holding hands. Ah, it's very emotional. They cry, we also get carried away a bit... you know, if we let ourselves get into it (female, 26 October 2016).

Thus, the immersive power of the staged performance creates a sense of place and engenders emotionality and cultural presence emanating from the fictionalised re-enactment of ancient religious practices, even when openly marketed as such (Pujol \& Champion, 2012). The creative skills of tourism providers operating in the public sector also contribute to enhance archaeological heritage, as is evident from the workshop on Alentejo's shale plates organised by the Archaeological Interpretation Centre of Évora (the capital city of Central Alentejo 
region). These ornamental artefacts consist of small pieces of shale with a variety of carved patterns and are extensively found in prehistoric burial sites across Alentejo. The experimental archaeology workshop enabled participants to learn about the plates' historical significance and providers to engage in participative co-creation of archaeological tourism:

I explained the shale plates and what they symbolised in prehistory. Then a jeweller ran a workshop, and each participant took home a piece. It's 'do it yourself', but inspired by local archaeological heritage (Évora's council archaeologist, male, 20 October 2016).

This demonstrates how providers utilise archaeological elements to inform a creative activity that neither depends nor focuses on the original artefacts. Instead, the process of experimentation is highlighted, shifting the focus away from the artefacts towards tourists' creative experience (Richards \& Wilson, 2006). The artistic residences program organised by Alqueva dam developers has produced local art installations such as the one depicted in Fig. 5. The word "LUZ" painted across an old road at a spot where the road dips under water and reappears again is a potent example of developer-funded efforts at retaining the essence of place. The now-submerged road has become a meeting space for diverse audiences (e.g. dam developers, tourists, providers and residents) as they affirm their connectivity to the region's past and present.

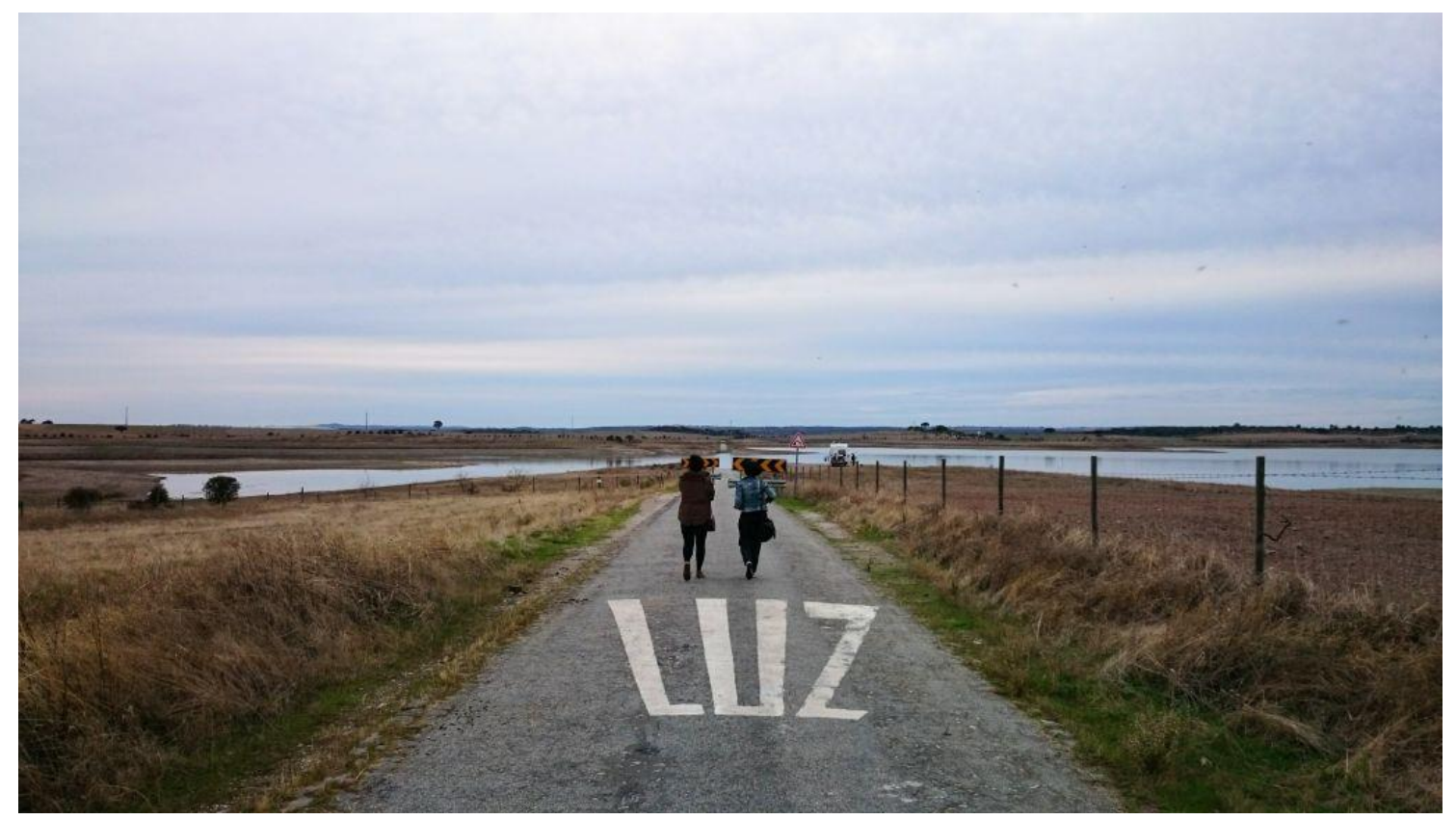

Figure 5. Memorialising the lost Luz village. Source: authors. 
Situated prominently within Alentejo's historic landscape, LUZ has become emblematic of the interpretation-oriented methodologies and creative storytelling that are fast assuming significance as means to interface with the region's offerings.

\subsection{Creative storytelling}

Overall, the discussion has shown how archaeological heritage in Alentejo is embedded in place (e.g. Alqueva lake) that on the surface has other uses and meanings, but the aspect "unavailable to vision" is being used creatively to inform memorable experiences. Tourism providers are key in facilitating sense-making because "the tourist who goes alone is completely lost since the place itself has absolutely nothing" (Alandroal's council archaeologist, female, 26 October 2016). Where there is a lack of material evidence, the intangible can only be experienced via the intervention of tourism providers who resort to secondary elements (e.g. landmarks, stories, pictures) as proxies to enable tourists to envision sites that have been destroyed (Suntikul \& Jachna, 2016). This is evident from the cultural tour Évora Desaparecida (Lost Évora), which focuses specifically on the process of demolition, destruction and reconstruction. In interpreting the "missing" features of Évora's heritage, a key element is the social framing of memory (see Halbwachs, 1992) as tour guides undertake the task of reproducing the remembered, e.g. through the use of images that depict monuments in an intact state (Fig. 6).

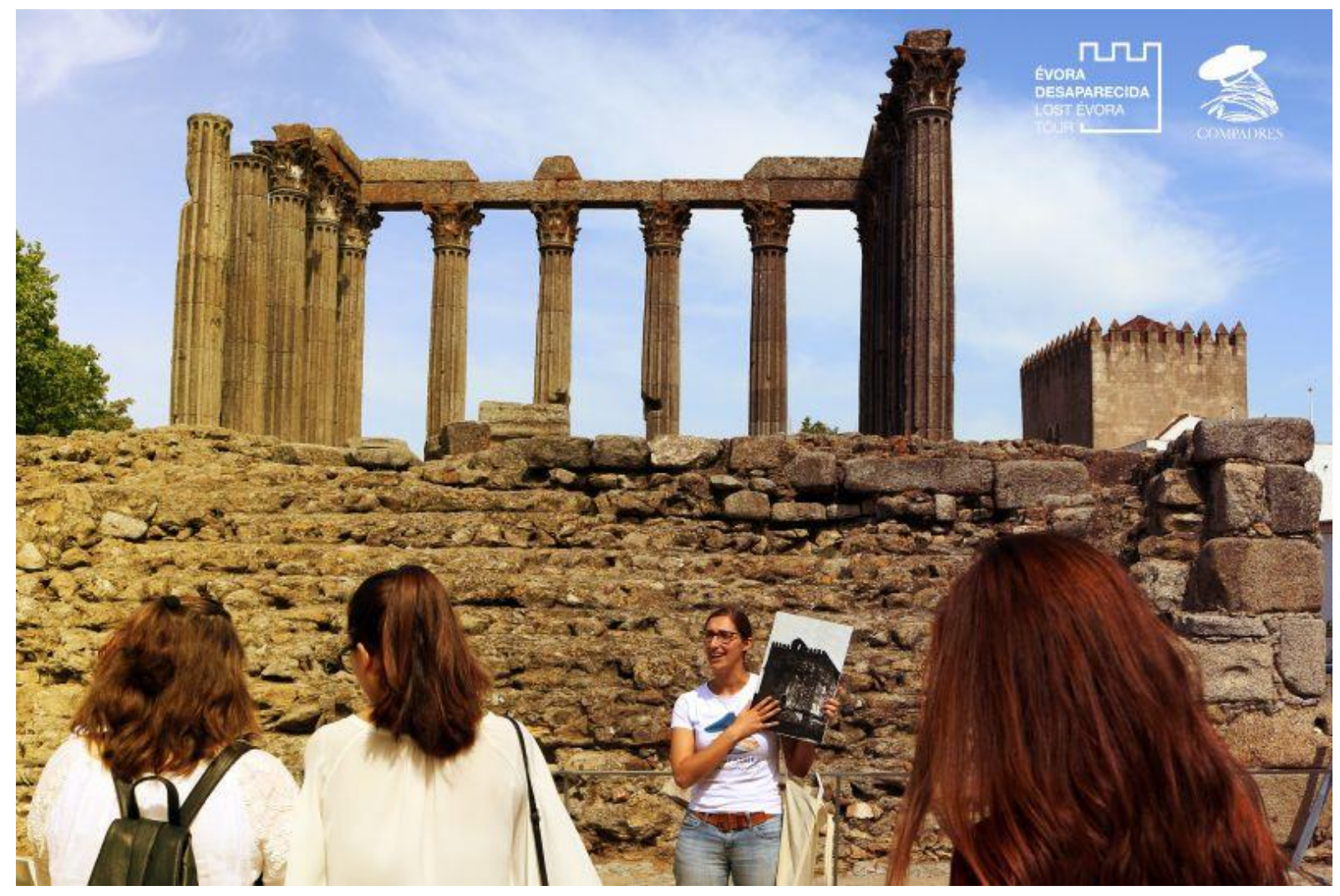


Figure 6. A tour guide leading the Évora Desaparecida tour. Source: Spira (picture reproduced with permission).

Tour guides draw attention away from the materiality by applying constructivist interpretation strategies to highlight “. . . concepts and ideas ... The sites are more of an excuse to talk about other things" (tour guide/archaeologist, male, 20 June 2016). We argue that this minor "talk about other things" or the mundane not only serves as means to consolidate alternative counter-discourses running parallel to the dominant authorised heritage discourse (see Smith, 2006), but also negotiate and (re)construct the tourism purpose of these "blank" spaces within the landscape. For example, we noted providers frequently included stories about growing up around megalithic monuments and shared their childhood experiences. Thus, the participative co-creation of the inaccessible heritage also takes place at the level of discourse (e.g. through an exchange of familial narratives) that enables, explicitly and/or implicitly, the process of negotiating meanings and understandings of both the past and the present (Carman, 2002). Thus, in the absence of tangible archaeological remains, the "black pigs" story becomes one of many visual references with which to entrench the appeal of the region's cultural, mystic heritage:

Some tourists ask to see black pigs in the countryside. Of course, it's easy to create that experience. But I take that opportunity to associate the pig to berrões, which were those Lusitanian symbols from northern Portugal. (...) Tourists think they are just going to see pigs and eat sausage, but then I-in my interpretation-I associate the pig to something more than just food, but almost as a religious animal with a Celtic background, which in turn has megalithic origins (tour guide, male, 7 June 2016).

Also, this participant's story does not remain solely restricted to the object of the tour (e.g. Alentejo's black pigs), but includes references to archaeological artefacts from northern Portugal. Although those artefacts are not physically present, tourists engage with them through the guide's creative ability and storytelling. Such ideas denote a Pro-c creativity in which tour guides' creative interpretation skills afford them an advantage over the mainstream competitors who apply little-c creativity in product development. While Alentejo's providers are not necessarily creating absolute breakthroughs (i.e. big-C creativity), they are bringing about what Maxwell and Hadley (2011) call an "artful integration" of archaeological knowledge into the broader tourism discourse prevalent on the region.

Furthermore, providers' interest in both inaccessible and relocated archaeological remains can also be explained by the investment theory of creativity, which argues that creative people are more likely to identify potentially valuable ideas and resources that are generally 
overlooked (Sternberg \& Lubart, 1991). For instance, a tour guide who only considers historical monuments with an exceptional value is not especially creative, but providers who are more open to investing time, energy and resources towards archaeological heritage with apparently lesser value (e.g. physically inaccessible) demonstrate greater creative capacity, despite the risks and marketing challenges presented. If successful in crafting a memorable experience around the intangible, tourism providers benefit from a lesser known resource that is vital in differentiating their offer. The investment theory helps explain why some tour guides choose to include destroyed archaeological sites within their tours and narratives, investing their time and skills into delivering a more enriched and memorable experience, while others focus largely on replicating conventional forms of archaeological tourism.

\subsection{Co-creative archaeological tourism}

It is clear that a co-creative approach that builds on providers' creativity, while simultaneously stimulating tourists' emotive and intellectual connections with the (im)materiality of the past, expands both access and relevance of historic sites for the purchasing public (Poria, Butler, \& Airey, 2003; Prebensen et al., 2013). Our findings suggest that, in general, the physical destruction of archaeological heritage drives creative tourism development by offering a new element for narrative building: the appeal of loss (Fig. 7). As seen in Alentejo, physical loss (e.g. the submerged Castle of Lousa) or conceptual loss (e.g. the relocated Xerez Cromlech) transforms and even replaces the monument's tangible appeal. In fact, physical destruction provides an impetus to what Melotti (2011) calls the emotive and sensory function of archaeological tourism, in which "the monument [or artefact] is no longer important in itself for its historical significance or as a key to understanding the culture and society of which it is an expression; it is important ... for its capacity to create an atmosphere in which we can live a particular experience" (p. 83). In this sense, a participative co-creation of archaeological heritage, delivered through providers' creative storytelling, invites the tourist's greater participation in co-creating experiences and narratives on the one hand and on the other positions affect and emotion as key constitutive elements of heritage-making. A practical example is the use of problem-solving situations, whereby providers ask tourists how and why they would have acted in a rescue archaeology situation, thus stimulating their involvement with the appeal of loss. In addition, themed activities such as re-enactments or experimental archaeology workshops serve as a creative outlet for both providers and tourists, as well as representing an effective means of memorialising heritage that has been physically lost, often using other local resources as supporting features (e.g. Alqueva lake). 


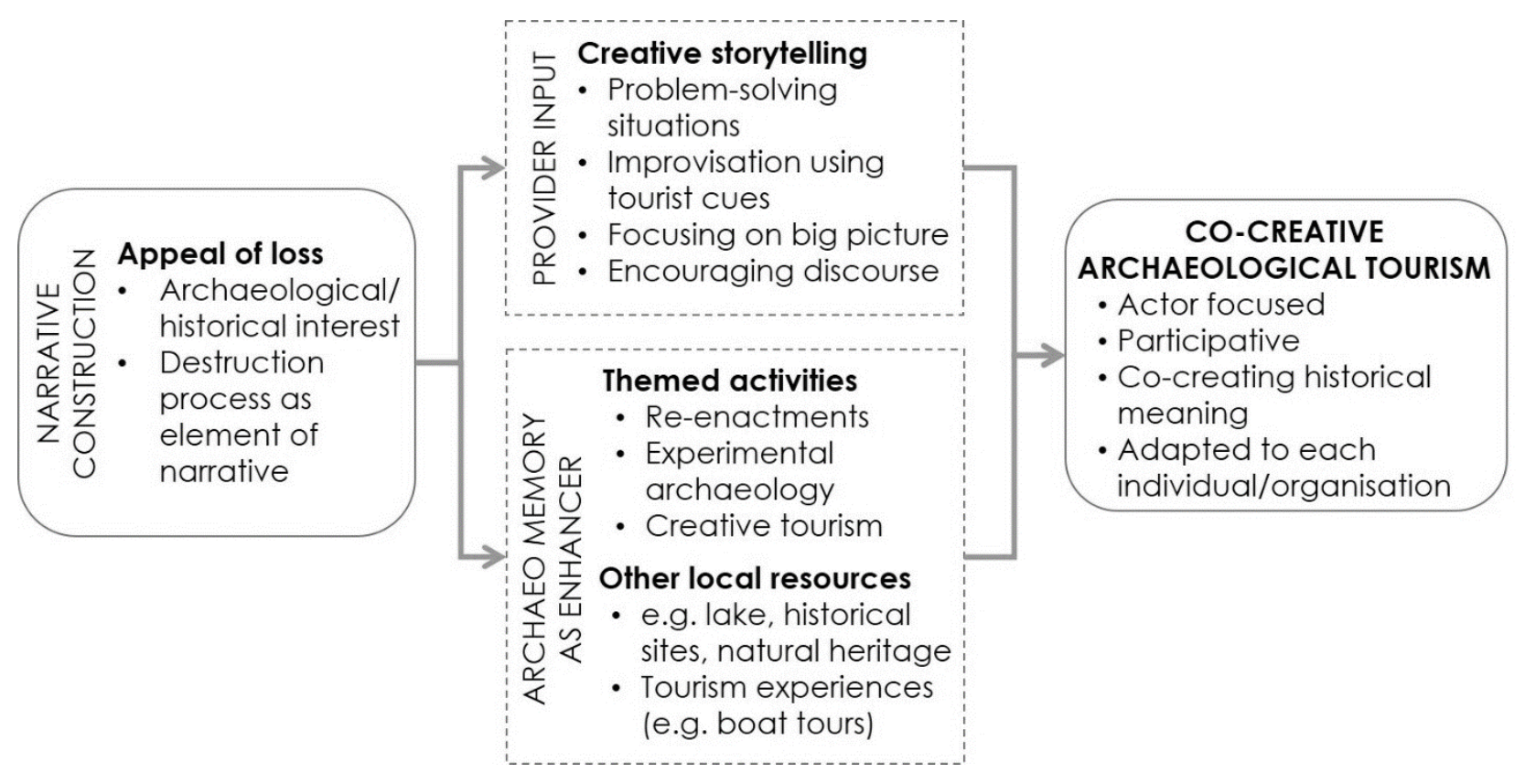

Figure 7. Appeal of loss as a driver of creative tourism. Source: authors.

In managerial terms, these findings imply three essential requirements for the successful development of co-creative archaeological tourism. First, it requires capacity building for cultural tourism actors focusing on co-creation strategies and creative skills and abilities, which nonetheless can be stimulated and improved upon (Nickerson, 1999). The investment theory underscores that creative individuals' ability to see value in little known ideas results of the confluence of six resources: a) intellectual skills; b) knowledge about the domain; c) progressive intellectual styles; d) personality traits that favour creativity; e) task-focused motivation; and f) an environment that is supportive of creative ideas. An initial assessment of providers against these resources could inform the development of tailored activities to improve specific skills, as is the case with Alentejo Criativo (Creative Alentejo), a programme recently organised to stimulate the regional creative and cultural industries (see www.alentejocriativo.net). This represents a conscious effort to promote and enhance tourism actors' creative abilities to higher levels (e.g. from little-c to Pro-c), in turn increasing chances of discovering value in destroyed archaeological heritage.

Second, providers are required to learn not only how to apply co-creative strategies, but also to understand what such an approach entails for heritage interpretation. A constructivist approach emphasises personal definition of heritage and identity, resulting in a plurality of archaeological interpretations suited to different purposes, needs and desires of those involved 
(Shanks \& Hodder, 1995). The tourist-centred approaches, grounded in a constructivist paradigm of heritage interpretation, imply that providers must be open to negotiate different views and accommodate the variety of references explored in co-creative sense-making, while maintaining their own assumptions. In fact, rather than providing a mere platform to promote the authorised scientific archaeological discourse, these participative archaeological tourism experiences offer tourists the opportunity to engage and reflect about the past as a means for self-reflection, identity-building and creative expression (Everett \& Parakoottathil, 2018).

Third, a creative approach to archaeological heritage requires an appreciation that the tourism value and role of heritage are not confined to its material dimension (Hodder, 2012; Smith, 2006). Thus, its destruction still has the potency to inform creative ventures and artistic or personal interpretation (Fibiger, 2015). While the conservation of material heritage remains paramount, acknowledging that sites and monuments are often lost allows us to work towards preserving what remains in situations in which material conservation is not possible. Indeed, our work demonstrates that co-creative archaeology-focused creative tourism initiatives serve as modes of preserving the memory and values associated with heritage that has lost its materiality due to targeted physical destruction.

\section{CONCLUSION}

In sum, we argue that our study into the participative co-creation of archaeological heritage enables the conceptual connection between the material loss of historic monuments and creative efforts at work that seek to minimise their disappearance at the symbolic level. Thus, this study adds to a growing body of literature on the social value of archaeological heritage (Parga \& González, 2019), specifically on the significance of placing "micro-stories" at the heart of archaeological interpretation experience (Ripanti \& Mariotti, 2018). This discourse is gaining currency in current creative tourism development and place-branding initiatives that aim to assimilate spaces that lie beyond pre-configured sets of commodified meanings. For instance, Creative Tourism Destination Development in Small Cities and Rural Areas (CREATOUR), a national three-year project, is currently seeking to (re)vitalise and valorise (in)tangible cultural assets in small cities and rural areas in Portugal (see http://creatour.pt/en). The emphasis is on developing artistic and creative industry hubs and re-purposing cultural elements to heighten their visibility (Duxbury \& Richards, 2019).

A key practical lesson that can be drawn from our findings is that the constructivist interpretation paradigm we propose serves as means of integrating alternative storylines and 
accommodating individuals' unique and reflective relationship(s) with the past. It makes way for, as Samuel (1994) argues, a critical view of the region's heritage as both "for the people" (official) and "of the people" (unofficial). Furthermore, establishing the tourism value of archaeological heritage that has been physically lost is helpful to cultural tourism businesses in terms of product diversification. Rather than proposing a substitute for conventional archaeological tourism, this approach both complements and enhances the current supply of creative experiences in heritage-rich destinations. Simultaneously, project developers operating in heritage-sensitive contexts gain insights into how impact can be minimised and the memory of affected heritage preserved for the benefit of local communities. However, not all participants in this study were fully aware of the archaeological heritage affected during the Alqueva dam construction, highlighting a need for collaboration between actors not traditionally associated (e.g. construction developers and cultural tourism businesses), perhaps mediated by local tourism or heritage authorities (Dias-Sardinha, Ross, \& Gomes, 2018). With a greater understanding of the magnitude of local archaeological interventions, these participants would have had more elements from which to reflect and offer informed comments. An element we did not consider, but one that is key in informing future studies in the field, is the role of tourists in the co-creation of cultural and creative tourism experiences. Further research is needed on how tourists' experience is influenced by a lack of the material presence of historic sites, as well as how this product influences tourism strategies geared towards attracting tourists to monuments in different states of conservation. It will be to interesting to document the role intangibility plays in generating new vectors of valorisation via marketing of novel immersive experiences that are desirable, deemed as socially necessary and yet commodifiable with a potential to sustain the region's economy.

Future studies could also examine how tourism providers manage conflicting interpretations emerging from participative co-creation and sense-making of archaeological heritage. An area of salient research relates to an examination of the intensity or depth of experience required in the participative co-creation of archaeological heritage (e.g. the extent to which communities are willing to share about their culture and tourists' willingness to absorb). Nevertheless, our work is timely in its attempt to shed light on the potential of participative co-creation in (re)defining and (re)configuring archaeological heritage to stretch the appeal of a place and afford legitimacy to disparate emotions and values attached to the past. 


\section{References}

Abu-Khafajah, S., \& Rababeh, S. (2012). The silence of meanings in conventional approaches to cultural heritage in Jordan: The exclusion of contexts and the marginalisation of the intangible. In M. L. Stefano, P. Davis, \& G. Corsane (Eds.), Safeguarding Intangible Cultural Heritage (pp. 71-83). Woodbridge: Boydell Press.

Adams, W. Y. (2007). A century of archaeological salvage, 1907-2007. Sudan \& Nubia, 11, 48-56.

Amabile, T. M. (1983). The social psychology of creativity. New York: Springer-Verlag.

Beghetto, R. A., \& Kaufman, J. C. (2007). Toward a broader conception of creativity: A case for "mini-c" creativity. Psychology of Aesthetics, Creativity, and the Arts, 1(2), 73-79. doi:10.1037/1931-3896.1.2.73

Binkhorst, E., \& Den Dekker, T. (2009). Agenda for co-creation tourism experience research. Journal of Hospitality Marketing \& Management, 18(2-3), 311-327. doi:10.1080/19368620802594193

Boyd, W. E. (2012). ‘A Frame to Hang Clouds on': Cognitive Ownership, Landscape, and Heritage Management. In R. Skeates, C. McDavid, \& J. Carman (Eds.), The Oxford Handbook of Public Archaeology (pp. 172-198). Oxford: Oxford University Press.

Bryman, A. (2012). Social Research Methods (4th ed.). Oxford: Oxford University Press.

Campos, A. C., Mendes, J., Valle, P. O. d., \& Scott, N. (2015). Co-creation of tourist experiences: A literature review. Current Issues in Tourism, 21(4), 369-400. doi:10.1080/13683500.2015.1081158

Carboni, N., \& de Luca, L. (2016). Towards a conceptual foundation for documenting tangible and intangible elements of a cultural object. Digital Applications in Archaeology and Cultural Heritage, 3(4), 108-116. doi:10.1016/j.daach.2016.11.001

Carman, J. (2002). Archaeology and heritage: An introduction. New York: Continuum.

Cohen, E. (1988). Authenticity and commoditization in tourism. Annals of Tourism Research, 15(3), 371-386. doi:10.1016/0160-7383(88)90028-X

Copeland, T. (2006). Constructing pasts: Interpreting the historic environment. In A. Hems \& M. Blockley (Eds.), Heritage Interpretation (pp. 83-95). London: Routledge.

Crang, M., \& Tolia-Kelly, D. P. (2010). Nation, Race, and Affect: Senses and Sensibilities at National Heritage Sites. Environment and Planning A: Economy and Space, 42(10), 2315-2331. doi:10.1068/a4346

De Cesari, C. (2010). Creative Heritage: Palestinian Heritage NGOs and Defiant Arts of Government. American Anthropologist, 112(4), 625-637. doi:10.1111/j.15481433.2010.01280.x

Demoule, J.-P. (2012). Rescue Archaeology: A European View. Annual Review of Anthropology, 41(1), 611-626. doi:10.1146/annurev-anthro-092611-145854

DeSilvey, C. (2017). Curated Decay: Heritage beyond saving. Minneapolis: University of Minnesota Press.

Dias-Sardinha, I., \& Ross, D. (2015). Perceived impact of the Alqueva dam on regional tourism development. Tourism Planning \& Development, 12(3), 362-375. doi:10.1080/21568316.2014.988880

Dias-Sardinha, I., Ross, D., \& Gomes, A. C. (2018). The clustering conditions for managing creative tourism destinations: the Alqueva region case, Portugal. Journal of Environmental Planning and Management, 61(4), 635-655. doi:10.1080/09640568.2017.1327846

Duxbury, N., \& Richards, G. (2019). A Research Agenda for Creative Tourism. Cheltenham: Edward Elgar.

Ellenberger, K. (2017). Virtual and augmented reality in public archaeology teaching. Advances in Archaeological Practice, 5(3), 305-309. doi:10.1017/aap.2017.20 
Everett, S., \& Parakoottathil, D. J. (2018). Transformation, meaning-making and identity creation through folklore tourism: the case of the Robin Hood Festival. Journal of Heritage Tourism, 13(1), 30-45. doi:10.1080/1743873X.2016.1251443

Fibiger, T. (2015). Heritage erasure and heritage transformation: how heritage is created by destruction in Bahrain. International Journal of Heritage Studies, 21(4), 390-404. doi:10.1080/13527258.2014.930064

Flick, U. (2014). An introduction to qualitative research (5th ed.). London: Sage.

Gardner, H. (1993). Creating minds: An anatomy of creativity seen through the lives of Freud, Einstein, Picasso, Stravinsky, Eliot, Graham, and Gandhi. New York: Basic Books.

Gibbs, G. (2007). Analyzing Qualitative Data. In. Retrieved from http://methods.sagepub.com/book/analyzing-qualitative-data doi:10.4135/9781849208574

Goudswaard, B., Bos, J., van Roode, S., \& Pape, H. (2012). Forward with reverse archaeology. Heritage \& Society, 5(1), 101-115. doi:10.1179/hso.2012.5.1.101

Guerra, A., Schattner, T., Fabião, C., \& Almeida, R. (2003). Novas investigações no santuário de Endovélico (S.Miguel da Mota, Alandroal): a campanha de 2002. Revista Portuguesa de Arqueologia, 6(2), 415-479.

Halbwachs, M. (1992). On Collective Memory. Chicago: University of Chicago Press.

Hein, G. E. (1998). Learning in the museum. London: Routledge.

Hodder, I. (2012). Entangled: An Archaeology of the Relationships between Humans and Things. Chichester: Wiley-Blackwell.

Holtorf, C. (2008). Is the past a non-renewable resource? In G. Fairclough, R. Harrison, J. Jameson Jr, \& J. Schofield (Eds.), The Heritage Reader (pp. 125-133). London: Routledge.

Holtorf, C. (2015). Averting loss aversion in cultural heritage. International Journal of Heritage Studies, 21(4), 405-421. doi:10.1080/13527258.2014.938766

Hubbard, P., \& Lilley, K. (2000). Selling the past: Heritage-tourism and place identity in Stratford-upon-Avon. Geography, 85(3), 221-232.

Huvila, I. (2017). Land developers and archaeological information. Open Information Science, 1, 71-90. doi:10.1515/opis-2017-0006

Jorgensen, A., Dobson, S., \& Heatherington, C. (2017). Parkwood Springs - A fringe in time: Temporality and heritage in an urban fringe landscape. Environment and Planning A: Economy and Space, 49(8), 1867-1886. doi:10.1177/0308518x17704202

Kaufman, J. C., \& Beghetto, R. A. (2009). Beyond big and little: The four C model of creativity. Review of General Psychology, 13(1), 1-12. doi:10.1037/a0013688

Kersel, M., \& Luke, C. (2004). Selling a replicated past: Power and identity in marketing archaeological replicas. Anthropology in Action, 11(2/3), 32-43.

Lin, P. M. C., \& Baum, T. (2016). The meaning of applied creativity in the culinary industry. International Journal of Hospitality \& Tourism Administration, 17(4), 429-448. doi:10.1080/15256480.2016.1226153

Lynn, P. (2004). Show Card. In M. S. Lewis-Beck, A. Bryman, \& T. F. Liao (Eds.), The SAGE Encyclopedia of Social Science Research Methods (pp. 1031). Thousand Oaks: Sage. doi:10.4135/9781412950589.n917

Maxwell, M., \& Hadley, P. (2011). TAG 2010 Session Review: An Artful Integration? Possible futures for archaeology and creative work. Retrieved from https://web.stanford.edu/dept/archaeology/cgi-bin/archaeolog/?p=325

McKercher, B., \& Ho, P. S. Y. (2006). Assessing the tourism potential of smaller cultural and heritage attractions. Journal of Sustainable Tourism, 14(5), 473-488. doi:10.2167/jost620.0 
McManamon, F. P. (1993, 30 July - 4 August). Linking Archaeology and Tourism. Paper presented at the ICOMOS International Scientific Symposium: Cultural Tourism, Colombo, Sri Lanka.

Melotti, M. (2011). The Plastic Venuses: Archaeological Tourism in Post-Modern Society. Newcastle upon Tyne: Cambridge Scholars Publishing.

Morgan, M., Elbe, J., \& Curiel, J. d. E. (2009). Has the experience economy arrived? The views of destination managers in three visitor-dependent areas. International Journal of Tourism Research, 11(2), 201-216. doi:10.1002/jtr.719

Nickerson, R. S. (1999). Enhancing creativity. In R. J. Sternberg (Ed.), Handbook of Creativity (pp. 392-430). Cambridge: Cambrige University Press.

Parga, E. D., \& González, P. A. (2019). Sustainable tourism and social value at World Heritage Sites: Towards a conservation plan for Altamira, Spain. Annals of Tourism Research, 74, 68-80. doi:10.1016/j.annals.2018.10.011

Poria, Y., Butler, R., \& Airey, D. (2003). The core of heritage tourism. Annals of Tourism Research, 30(1), 238-254. doi:10.1016/s0160-7383(02)00064-6

Prebensen, N. K., Vitters $\varnothing$, J., \& Dahl, T. I. (2013). Value co-creation significance of tourist resources. Annals of Tourism Research, 42, 240-261. doi:10.1016/j.annals.2013.01.012

Pujol, L., \& Champion, E. (2012). Evaluating presence in cultural heritage projects. International Journal of Heritage Studies, 18(1), 83-102. doi:10.1080/13527258.2011.577796

Quan, S., \& Wang, N. (2004). Towards a structural model of the tourist experience: an illustration from food experiences in tourism. Tourism Management, 25(3), 297-305. doi:10.1016/S0261-5177(03)00130-4

Ramsey, D., \& Everitt, J. (2008). If you dig it, they will come: Archaeology heritage sites and tourism development in Belize, Central America. Tourism Management, 29, 909-916. doi:10.1016/j.tourman.2007.11.002

Rana, J., Willemsen, M., \& Dibbits, H. C. (2017). Moved by the tears of others: emotion networking in the heritage sphere. International Journal of Heritage Studies, 23(10), 977-988. doi:10.1080/13527258.2017.1362581

Richards, G., \& Wilson, J. (2006). Developing creativity in tourist experiences: A solution to the serial reproduction of culture? Tourism Management, 27(6), 1209-1223. doi:10.1016/j.tourman.2005.06.002

Richards, R. (2010). Everyday creativity: Process and way of life - four key issues. In J. C. Kaufman \& R. J. Sternberg (Eds.), The Cambridge Handbook of Creativity. New York: Cambridge University Press.

Ripanti, F., \& Mariotti, S. (2018). "The God of Time is Heritage of Mine": An emotional approach to public outreach in Vignale (Italy). Advances in Archaeological Practice, 6(3), 199-211. doi:10.1017/aap.2018.18

Ross, D., Saxena, G., Correia, F., \& Deutz, P. (2017). Archaeological tourism: A creative approach. Annals of Tourism Research, 67, 37-47. doi:10.1016/j.annals.2017.08.001

Roussou, M., Ripanti, F., \& Servi, K. (2017). Engaging visitors of archaeological sites through 'emotive' storytelling experiences: a pilot at the Ancient Agora of Athens. Archeologia e Calcolatori, 28(2), 405-420.

Saldaña, J. (2013). The coding manual for qualitative researchers (2nd ed.). London: Sage. Samuel, R. (1994). Theatres of Memory. London: Verso.

Shanks, M., \& Hodder, I. (1995). Processual, postprocessual, and interpretative archaeologies. In I. Hodder, M. Shanks, A. Alexandri, V. Buchli, J. Carman, J. Last, \& G. Lucas (Eds.), Interpreting archaeology: Finding meaning in the past (pp. 3-29). London: Routledge. 
Shurmer-Smith, P., \& Hannam, K. (1994). Worlds of Desire, Realms of Power: A cultural geography. London: Edward Arnold.

Silva, A. C. (2002). Alqueva - Cultural Resource Management (1997-2002). In EDIA (Ed.), Património Arqueológico: Investigação e Salvaguarda (1997-2002). Beja: EDIA.

Silva, A. C. (2004). Reinstalação do Cromeleque do Xerez. Beja: EDIA.

Silva, A. C. (2015). A reinvenção do Castelo da Lousa. Retrieved from http://pedrastalhas.blogspot.com/2015/12/a-reinvencao-do-castelo-da-lousa-no.html

Simpson, M. (2018). Heritage: Nonwestern Understandings. In The Encyclopedia of Archaeological Sciences. London: John Wiley and Sons.

Smith, L. (2006). The uses of Heritage. London: Routledge.

Sternberg, R. J. (2012). The assessment of creativity: An investment-based approach. Creativity Research Journal, 24(1), 3-12. doi:10.1080/10400419.2012.652925

Sternberg, R. J., Kaufman, J. C., \& Pretz, J. E. (2002). The Creativity Conundrum: A Propulsion Model of Kinds of Creative Contributions. New York: Psychology Press.

Sternberg, R. J., \& Lubart, T. I. (1991). An investment theory of creativity and its development. Human Development, 34(1), 1-31.

Sternberg, R. J., \& Lubart, T. I. (1996). Investing in creativity. American Psychologist, 51(7), 677-688. doi:10.1037//0003-066x.51.7.677

Suntikul, W., \& Jachna, T. (2016). The co-creation/place attachment nexus. Tourism Management, 52, 276-286. doi:10.1016/j.tourman.2015.06.026

Svensson, M. (2018). Heritage 2.0: Maintaining affective engagements with the local heritage in Taishun. In M. Svensson \& C. Maags (Eds.), Chinese Heritage in the Making: Experiences, Negotiations and Contestations (pp. 269-292). Amsterdam: Amsterdam University Press.

Timothy, D. J., \& Boyd, S. W. (2003). Heritage tourism. Harlow: Prentice Hall.

Turismo do Alentejo. (2015). Plano Estratégico para o Desenvolvimento do Touring Cultural e Paisagístico no Alentejo e Ribatejo. Retrieved from https://www.visitalentejo.pt/fotos/editor2/Quem\%20somos/plano_estrategico_touring cultural_e paisagistico-diagnostico_final.pdf

van der Linde, S., \& van der Dries, M. (2015). Creative archaeology. In M. van der Dries, S. van der Linde, \& A. Strecker (Eds.), Fernweh: Crossing borders and connecting people in archaeological heritage management (pp. 51-55). Leiden: Sidestone Press.

van der Linde, S. J., van den Dries, M. H., \& Wait, G. (2018). Putting the Soul into Archaeology-Integrating Interpretation into Practice. Advances in Archaeological Practice, 6(3), 181-186. doi:10.1017/aap.2018.22

Vargo, S. L., \& Lusch, R. F. (2004). Evolving to a new dominant logic for marketing. Journal of Marketing, 68(1), 1-17. doi:10.1509/jmkg.68.1.1.24036

Waitt, G., \& McGuirk, P. M. (1997). Selling waterfront heritage: A critique of Millers Point, Sydney. Journal of Economic and Social Geography, 88(4), 342-352. doi:10.1111/j.1467-9663.1997.tb01629.x

Warnaby, G., Medway, D., \& Bennison, D. (2010). Notions of materiality and linearity: the challenges of marketing the Hadrian's Wall place 'product'. Environment and Planning A, 42, 1365-1382. doi:10.1068/a42481

WCD. (2000). Dams and development: A new framework for decision-making (9781853837975). Retrieved from http://www.internationalrivers.org/files/attachedfiles/world_commission_on_dams_final_report.pdf

Weaver, D. B., \& Lawton, L. J. (2007). 'Just because it's gone doesn't mean it isn't there anymore': Planning for attraction residuality. Tourism Management, 28(1), 108-117. doi:10.1016/j.tourman.2006.01.002 
Willems, A., \& Dunning, C. (2015). Solving the puzzle: The characteristics of archaeological tourism. In M. van der Dries, S. van der Linde, \& A. Strecker (Eds.), Fernweh:

Crossing borders and connecting people in archaeological heritage management (pp. 68-71). Leiden: Sitestone Press.

Wu, Z., \& Hou, S. (2015). Heritage and Discourse. In E. Waterton \& S. Watson (Eds.), The Palgrave Handbook of Contemporary Heritage Research (pp. 37-51). London: Palgrave Macmillan UK.

Youngentob, K., \& Hostetler, M. (2003). Environmental interpretation: How to communicate persuasively. WEC 169. Retrieved from http://edis.ifas.ufl.edu/uw182 